\title{
Tanulmány
}

\author{
Bakaja Zoltán
}

\section{A Bhagavad-gītā As It Is fordításának egyes lexikai problémái}

\begin{abstract}
This study is explores how to solve some lexical problems which arise while translating the English book Bhagavadgītā As It Is by A. C. Bhaktivedanta Swami Prabhupāda into Hungarian. Most of the examined expressions fall into the category of realias, which are words difficult to translate because of their exclusive connection with a certain culture. In my work, I will not analyze the existing Hungarian editions, but rather I will consider questions which translators have to deal with when beginning their work. The expressions I will examine are the verb of the beszélöjelölö "speaker reference", living entity, self-realization, and the Supreme Personality of Godhead.

Keywords: Bhagavad-gītā, beszélőjelölő, living entity, self-realization, Supreme Personality of Godhead.
\end{abstract}

\section{Bevezetés}

Ebben a tanulmányban néhány olyan lexikai kérdéssel foglalkozom, amellyel az a fordító szembesül, aki A. C. Bhaktivedanta Swami Prabhupāda Bhagavad-gītā As It Is címü angol nyelvü könyvének magyarra fordítását tüzte ki céljául. Nem a már évtizedekkel ezelőtt megjelent magyar kiadásokat elemzem (noha hivatkozni fogok a bennük található megoldásokra), hanem olyan elméleti problémákat vizsgálok, amelyeken a fordítónak mindenképpen el kellene gondolkoznia, ha most kezdene neki a munkának. Nem szándékom választ adni minden egyes felmerülő kérdésre, pusztán a figyelmet akarom felhívni ezekre, s meg akarom mutatni, mit nyerhetünk és veszíthetünk egyes megoldások alkalmazásával. Az angol nyelvü forrásokból származó idézeteket a saját fordításomban közlöm.

A dolgozatban szereplö legtöbb kifejezés magyar nyelvre való átültetése a reáliák, a valamely kultúrához kizárólagosan kötődő tartalmuk miatt nehezen visszaadható szavak, kifejezések fordításának problémakörébe tartozik. A reália szónak a fordítástudományi szakirodalomban használt jelentéseiröl és szinonimáiról Mujzer-Varga Krisztinának a Forditástudomány címü folyóiratban megjelent cikke ad átfogó képet (2007). A szerző meglepetéssel jegyzi meg, hogy az általa feldolgozott 33 szakirodalmi tételben a fogalom tartalmának elemzésekor csak Newmark (1988) felosztása említi meg a vallási vonatkozást. Az általam vizsgált kifejezések közül hármat sorolhatunk e csoportba.

A Bhagavad-gītā As It Is első kiadása 1968-ban, Londonban, a Collier - Macmillan Ltd. kiadásában jelent meg először (1. URL). A kötet a Bhagavad-gītā szanszkrit versszakainak angol fordítása mellett Allen Ginsberg, Denise Levertov és Thomas Merton ajánlását, valamit a fordítónak a szanszkrit szöveghez füzött kommentárjait is tartalmazta. A mü címében szereplő as it is kifejezés 
arra utal, hogy A. C. Bhaktivednta Swami Prabhpāda-t, a fordító-kommentátort, munkája során a szöveg eredeti szellemben való tolmácsolásának szándéka vezette (2001: 2). A kiadó jelentősen megrövidítette az eredeti kéziratot, a münek az összes magyarázatot tartalmazó, teljes kiadása csak 1972-ben látott napvilágot (2. URL) s a mai formáját 1983-ban nyerte el (3. URL), immár a Bhaktivedanta Book Trust International, Inc. (4. URL) gondozásában. A legújabb kiadás elején a kiadónak a Mahābhārata - a Bhagavad-gītāt tartalmazó eposz - cselekményét felvázoló előszava, a szerző (a kommentároknak a fordított szöveget jóval meghaladó terjedelme miatt a fordítókommentátort a továbbiakban is szerzőnek nevezem) előszava és az általa írt bevezetés áll. Az egyes versszakokat először devanāgarī írással, utána annak latin betüs, mellékjeles átírásával olvashatjuk, ezt követi a versszak szavainak s végül a teljes versszaknak a fordítása. A kötet szinte minden versszaka után található egy kommentár, ezeket a szerzö purport-nak ('[vminek a] lényege/magva, értelem, jelentés, tartalom') ${ }^{1}$ nevezi.

Mielőtt belefognék az egyes lexikai egységekkel kapcsolatos kérdések tárgyalásába, beszélnem kell a magyar fordítónak a könyvhöz füződő viszonyáról, mert ez egészen biztosan hatással lesz az általa alkalmazott lexikai átváltási müveletekre is. A mü jogtulajdonosa a The Bhaktivedanta Book Trust International, Inc. A fordításon csak a szerző által alapított vallási szervezet, az ISKCON (5. URL) tagjai dolgozhatnak, és számukra Bhaktivedanta Swami Prabhupāda nem egyszerüen egy író vagy müfordító, hanem a közösség alapítója, akinek a munkásságát különös jelentőségünek tartják. Csak úgy lehet valaki a közösség képviselöje (pl. a Bhaktivedanta-könyvek fordítója), ha teljes mértékben elfogadja a Bhaktivedanta Swami Prabhupāda által tanított filozófiát, és változtatás nélkül mutatja azt be másoknak.

Annak, hogy egy müvet valamely közvetítőnyelven keresztül ültetnek át a célnyelvre, egyaránt lehet az oka az, hogy nem volt olyan fordító, aki az eredeti nyelvet beszélte volna, illetve az is, hogy a közvetítő nyelven alkotó fordító nem pusztán lefordította a forrásnyelvi szöveget, hanem egy bizonyos módon átalakította, értelmezte vagy valamilyen kiegészítést füzött hozzá. A szerző a jelen esetben egy adott fordítói és kommentátori hagyományt követve dolgozott, ezt a hagyományt örökítette tovább, és ennek kontextusában választotta ki a használandó célnyelvi szavakat, kifejezéseket. Ez nem jelenti azt, hogy átértelmezte a müvet, ám a mü adta kereteken belül egy jól elkülöníthető értelmezői hagyományt képvisel. Mivel a fordítás egy adott iskolán belül történik, $\mathrm{s} a$ fordító a szerzőt közössége alapítójaként tiszteli, munkája során végig mérlegelnie kell, hogy az általa választott megoldások vajon megőrzik-e a Bhaktivedanta-fordítás és magyarázatok szellemiségét, hangulatát, s alkalmasak-e arra, hogy lehetőleg minden olyan információt átadjanak, amely az angol forrásnyelvi szövegből megismerhető. Ennek köszönhetően azt is mérlegelnie kell, milyen esetekben kell ragaszkodnia az angol szöveghez való formahüséghez, s hogy a magyar fordítási normáknak vagy nyelvi sajátosságoknak megfelelendő, mikor kell és mikor szabad attól eltérnie.

\section{$2 \quad$ A beszélöjelölö igéjének fordítása}

Az első megvizsgálandó lexikai kérdés a Bhagavad-gītá első sorában található szanszkrit $u v \bar{a} c a$ szó fordításának mikéntje. Az 1. fejezet 1. versszaka a dhṛtarāṣțra uvāca ('Dhṛtarāșțra mondta') szavakkal kezdődik, az angol fordításban pedig azt olvashatjuk: Dhṛtarāṣtra said. Klaudy Kinga azt írja Bevezetés a forditás gyakorlatába címü könyvében, hogy a magyar fordítók a monotónia elkerülése végett a valamely indoeurópai nyelven írott szövegekben ismétlődő, mondást jelző alapigéket (say, sagen, сказать) általában konkretizálják (Klaudy 1999: 49). Egy másik müvében, az Angol-

\footnotetext{
A továbbiakban az angol szavak jelentését Országh és Magay nagyszótára (2009) alapján adom meg.
} 
Bakaja Zoltán: A Bhagavad-gìtā As It Is forditásának egyes lexikai problémái

Argumentum 15 (2019), 784-798

Debreceni Egyetemi Kiadó

DOI: $10.34103 / A R G U M E N T U M / 2019 / 5$

magyar fordítástechnikában négy típusát különíti el a konkretizálásnak (Klaudy \& Simigné 2000: $31-32):^{2}$

1) A magyar szöveg is mondást jelentő igéket tartalmaz, de az angolnál változatosabb módon használja öket: kezdte, közbeszólt, megszólalt, megnyilatkozott, hadarta, motyogta.

2) A konkretizálás során a fordítók a szereplők lelkiállapotát kifejező igéket választanak: hüledezett, csodálkozott.

3) A beszédet kísérő mozdulatokra utaló igék használata: bólintott, legyintett.

4) Olyan igék használata, amely csak az adott szituációban, alkalmilag helyettesítheti a mondást kifejező igéket: nyújtózott, bontogatta.

Klaudy e fordítói gyakorlat okát abban látja, hogy az eredetileg is magyar nyelven írt müvek szerzői az angol írók által alkalmazottnál változatosabb igekészletet használnak, így a fordítások olvasóinak a mondta állandó ismétlése monotonnak tünne (Klaudy \& Simigné 2000: 33).

Az uvāca a szanszkrit szövegek jellemző idéző igéje, a Bhagavad-gītāban 64-szer fordul elő. Minden egyes alkalommal ez a 2. igeragozási osztályú vac 'beszél' (Körtvélyesi 2006: 255) gyökből képzett, E/3 személyü, elbeszélő múlt idejü (befejezett), cselekvő ige jelzi a párbeszédek szereplőinek új megszólalását. A szanszkrit-angol szótár a gyök jelentését a speak, say, tell, utter, announce, declare, mention, proclaim, recite, describe szavakkal adja meg (Monier-Williams 2011). ${ }^{3}$ Az angol fordításokban az $u v \bar{a} c a$ megfelelőjeként általában a said ('szólt, beszélt, mondta') ${ }^{4}$ használatos. A könyvben 60 -szor előforduló alany+uvāca szerkezet az új megszólalások jelölésére szolgál, illetve amennyiben a szereplö már egy korábbi fejezetben elkezdett beszélni, a következő fejezetek elején biztosítja, hogy tudjuk kinek a szavait halljuk. E szerkezet nem jelenik meg a müben következetesen minden egyes megnyilatkozás előtt. Amikor például az 1 . fejezet 3 . versszaka Duryodhanát idézi, nem szerepel a szövegben a duryodhana uvāca, ám a legtöbb esetben ott találjuk az új megszólalások elött. Ezt az alany+uvāca szerkezetet a továbbiakban beszélöjelölönek hívom.

E szerkezet használata sokszor formális, a beszélőjelölő akkor is ott áll, ha pontosan tudjuk, hogy a következő versszak kinek a szájából fog elhangozni. Az 1. fejezet 27. versszaka az idam abravit ('így szólt') szavakkal végződik, az előzőekből pedig már tudjuk, hogy Arjunáról van szó, a 28. versszakban mégis feltünik a beszélőjelölö: arjuna uvāca. Az is megesik, hogy az előző versszak vége ugyanezzel az igével utal az újonnan megszólaló személyére. Ezt láthatjuk a 2 . fejezet 1. versszakában, amely az uvāca madhusūdhanaḥ ('Madhusūdana [Kṛ̣ṇa egyik neve] mondta') szavakkal végződik. Ennek ellenére a következö versszak előtt ismét azt olvashatjuk: śri-bhagavān uvāca ('a fenséges Úr mondta').

Az eddigiek alapján azt gondolhatnánk, hogy a Bhagavad-gìtā As It Is szintén a said-et használja az $u v a \bar{c} a$ fordításaként, és a magyar fordítónak azt kell eldöntenie, milyen lexémával adja vissza az $u v \bar{a} c a-$ said jelentését és milyen mértékben éljen a magyar fordítási normának is mondható célnyelvi változatosság megteremtésével. A Klaudy és Simigné által bemutatott példák mind szépirodalmi szövegekböl származnak, a Bhagavad-gītā azonban nem pusztán szépirodalmi mü, Vekerdi József a vallásbölcseleti költemény kategóriába sorolja (Lakatos \& Vekerdi 1987: 173).

A Klaudy és Simigné példáiban található konkretizálás az irodalmi minőség megteremtésére irányult. A Bhagavad-gītā esetében az az egyik eldöntendö kérdés, hogy vajon a konkretizálás

2 Simigné a könyv második részét írta, azért jelölöm meg a hivatkozott szöveg szerzőjeként Klaudyt, mert az általam hivatkozott első rész teljes egészében az ő munkája.

3 A továbbiakban szanszkrit-angol szótár alatt mindig a hivatkozásban szereplő szótárat értem.

4 A továbbiakban az angol szavak jelentését Országh és Magay nagyszótára (2009) alapján adom meg. 
befolyásolná-e a vallási vagy a filozófiai tartalmat. Bhaktivedanta Swami Prabhupāda könyveit tanulmányozva azt látjuk, hogy az általa lefordított müvekben az uvāca szóval hivatkozott szöveg nem kötődik egy meghatározott személyhez vagy nézethez, éppúgy elhangozhat Isten vagy a démonok szájából, ahogyan különféle, akár egymásnak ellentmondó filozófiák követőinek a szájából is (6. URL). A célnyelvi megfelelő megváltoztatása tehát nem fog elhomályosítani valamilyen egységes vallási vagy filozófiai tartalomra való utalást. Ezek szerint nincs tartalmi akadálya annak, hogy a forrásnyelvi szöveg idéző igéjét célnyelvi megfelelőjének több szinonimáját használva vagy konkretizált formában fordítsuk le.

Milyen lehetőségeket kínál a szöveg szerkezete a fordító számára, és milyen nehézségekkel találja magát szembe e munka során? A magyar szövegekben az idéző igéket sokszor a mondatok, tagmondatok, illetve a megszólalás végén találjuk: ... - mondta az alany. Ha az idézö ige egy párbeszédben sok mondaton keresztül ugyanazon a helyen áll, az monotonitást eredményez. Az Angol-magyar forditástechnikában ugyan találhatunk egy példát, ahol az alany három egymást követő mondatban is az idéző ige előtt áll, de ezt a megoldást nehézkesnek érzem (Christie 1968: 144, idézi: Klaudy \& Simigné 2000: 31):

Négyen vagyunk és nem tudjuk, ki a... - kezdte Amstrong.

Blore közbeszólt - Én tudom.

Vera is megszólalt - Én is tökéletesen biztos vagyok benne.

Philip Lombard is megnyilatkozott - Úgy érzem, én is biztos vagyok benne.

A fordító, Szíjgyártó László megoldásában a második mondat alanyának előrehelyezése feszültséget teremt, ami alkalmas eszköz a közbevágás hirtelenségének az érzékeltetésére. Az is használatával ezt a feszültséget a harmadik mondatban is fenn tudja tartani, s ebböl a szempontból az igekötőknek is fontos szerepük van, ám a negyedik mondatban megismételt $i s$, és az azt követő szintén ismétlődő igekötő miatt a szöveg végül ellaposodik. Az idéző mondategység és az idézet felcserélése továbblendíthette volna a beszélgetést:

Négyen vagyunk és nem tudjuk, ki a... - kezdte Amstrong.

Blore közbeszólt - Én tudom.

Vera is megszólalt - Én is tökéletesen biztos vagyok benne.

Úgy érzem, én is biztos vagyok benne - csatlakozott Philip Lombard.

A magyar szövegekben tehát nem gyakori és nem hat természetesen az alanynak az idéző ige elé helyezése; különösen akkor teszi döcögőssé a müvet, ha sokszor ismétlődik. A Bhagavad-gītāban persze a megszólalók személye nem változik ilyen rövid időn belül, így a monotonitás érzete sem lesz a fenti példához hasonlóan erős.

Mit tehet a fordító, ha úgy akarja a versszakok elején tartani a jelölöt, hogy közben elkerülje, hogy a szöveg statikussá váljon? Baktay Ervin olyan megoldást választott, amellyel mindkét célt elérte: a szerkezetből csak az alanyt hagyta meg. A versszakok előtt csak a kiskapitálissal szedett nevek állnak, s ez olyan képzetet kelt, mintha egy drámát vagy egy opera szövegkönyvét olvasnánk. Mivel ebben az esetben a jelölő nyilvánvalóan elkülönül a szövegtől, használata magát a szöveget nem teszi statikussá (Baktay 2013): 
DHRITARÁSTRA:...

SZANDZSAJA:...

ARJUNA:...

SZANDZSAJA:...

Gömöryné Maróthy Margit valami hasonlóval kísérletezik, de Baktayhoz képest kevésbé radikális. A múlt idejü szanszkrit igét jelen időben használja, ami segít érzékeltetni a jelölőnek az egyébként múlt időben íródott történettől való különállóságát, narratív jellegét (1924):

Dhritarástra szól: ...

Sanydzsaja szól: ...

Bhaktivedanta Swami Prabhupāda a szanszkritról angolra való fordítás során néhol maga is konkretizálja az idéző igét, egy helyen a replied ('felelt') (5.2), egy másikon az answered ('válaszolt') (17.2), négy esetben pedig az inquired ('kérdezte') áll a jelölö igei részében (8.1, 12.1, 14.21, 17.1). Ha a fordító a kihagyást, a Baktay által használt átváltási müveletet választja, hiányos mondat keletkezik, amelyben a mellőzött igét a kettőspont vagy valamilyen tipográfiai megoldás helyettesíti, így azonban elvész az angol fordító által alkalmazott konkretizálás megmutatásának lehetősége. A tipográfiai hatás sem lehet ugyanolyan, mint Baktay könyvének esetében, ahol a beszélök neve kiemelkedik a sorok közül. A Bhagavad-gītā As It Is-ben a fordítás elött ott áll a devanāgarī-val írt szanszkrit, annak latin betűs átírása és a szószedet is. Ezek után értelmetlen lenne külön sorba szedni a beszélő nevét, ez nem segítené jobban az olvasó tájékozódását. Jó példa erre a könyv magyar fordításának első kiadása (Bhaktivedanta é. n.), ${ }^{5}$ amelyben a beszélőjelölő külön sorba került, de nem ragadja meg az ember tekintetét úgy, ahogyan azt Baktay fordításának esetében tapasztalhatjuk.

Az elöbb említett elemek jelenléte egy másik megoldás lehetőségét is felveti, hiszen általuk a tagolás és a beszélő kilétének jelzése már úgyis megvalósul. Mivel jól látható, hogy ki beszél, a beszélőjelölö fordítását a mondat végére tehetjük vagy másutt is elhelyezhetjük a szövegben. Ez azonban nem müködik jól azokban az esetekben, amikor magukban a versszakokban is arról esik szó, hogy valaki beszél, vagy abban a korábban már említett példában, amikor a versszakból megtudhatjuk, hogy a következőben ki veszi át a beszélgetés fonalát (2.1-2):

Sañjaya said: Seeing Arjuna full of compassion, his mind depressed, his eyes full of tears, Madhusūdana, Kṛ̣na, spoke the following words.

The Supreme Personality of Godhead said: My dear Arjuna, how have these impurities come upon you? They are not at all befitting a man who knows the value of life. They lead not to higher planets but to infamy.

A fenti példában mindenképpen jobb, ha az első beszélőjelölő a fordításban a mondat elejére kerül, és az idéző igét is ajánlatos konkretizálni, hiszen a Sañjaya said az 1. fejezet utolsó versszakában is ott állt:

Sañjaya folytatta: Miután Madhusūdana látta, hogy Arjuna szeme megtelt könnyel s eluralkodott rajta az együttérzés és a szomorúság, a következö szavakkal feddte öt meg:

\footnotetext{
5 A kiadáson nincs feltüntetve az évszám, de abból, hogy a magyar fordító előszava 1981 decemberi keltezésű, arra
} következtethetünk, hogy a könyv 1982-ben jelent meg. 
Bakaja Zoltán: A Bhagavad-gītā As It Is forditásának egyes lexikai problémái

Argumentum 15 (2019), 784-798

Debreceni Egyetemi Kiadó

DOI: $10.34103 / A R G U M E N T U M / 2019 / 5$

Kedves Arjunám, hogyan keríthettek hatalmukba e tisztátlan gondolatok, amelyek egyáltalán nem illenek ahhoz, aki ismeri az élet értékét? Ezek nem magasabb világokba emelnek, hanem csak rossz hírbe hoznak! - mondta a mindenek fölött álló Isten.

Ebben az esetben megint azzal találjuk szembe magunkat, hogy a jelölő konkretizálása miatt - hacsak nem jelezzük egy lábjegyzetben vagy valamilyen kiegészítő fejezetben - nem tudjuk megmutatni azt, melyek azok a helyek, ahol az angol fordító is alkalmazta ezt az átváltási müveletet.

Nem ez az egyetlen probléma a hátravetett beszélöjelölövel. A Bhagavad-gītānak vannak olyan fejezetei, amelyekben a jelölő csak egyetlen egyszer, a fejezet elején található meg, mert az egész fejezetben csak egyvalaki beszél. Ilyen a 15. és a 16. fejezet is, Kṛ̣ṇa monológja viszont már korábban, a 14. fejezet 22. versszakában elkezdődik. Ezekben az esetekben nem lenne értelme a jelölő fejezet végén való alkalmazásának, hiszen éppen az funkciója, hogy a befogadóval már a fejezet elején tudassa, hogy éppen kinek a szavait olvassa. Ezt a megoldást tehát el kell vetnünk. Vagy a fejezetek 1. versszaka elé tesszük a jelölöt: A mindenek fölött álló Isten folytatta:, vagy be kell építenünk az 1. versszak szövegébe:

Azt mondják - folytatta a mindenek fölött álló Isten - van egy elpusztíthatatlan... (15.1)

A félelem hiánya - folytatta a mindenek fölött álló Isten -, létünk megtisztítása... (16.1)

Ehhez hasonlóan járhatunk el akkor is, ha a jelölő hosszabb szövegrészt vezet be: háromnál több versszak esetén nem érdemes a megszólalás végére hagyni. Vagy meg kell, hogy előzze a megszólalást, vagy be kell építeni az újonnan megnyilatkozó szereplő által mondott első versszakba (14.22):

A mindenek felett álló Isten válaszolt neki:

Pṛthā fia - felelte a mindenek felett álló Isten - ,

Ahogy azt a fentiekből láthatjuk, ha megfelelő helyre illesztjük be, akkor a beszélőjelölő szövegbe való integrálása jól müködik, ám ezzel elveszítjük annak lehetőségét, hogy a konkretizálást csak azokban az esetekben végezzük el, amikor ezt az angol fordító is megtette.

Akár elkülöníti, akár integrálja a versszakba a beszélőjelölőt, a fordítónak el kell döntenie, hogy milyen magyar szót fog használni az uvāca-said lexéma fordítására. Ha nem fukarkodik a konkretizálással, a kérdezte, felelte, válaszolt, folytatta stb. ízlés szerinti alkalmazása áll előtte lehetőségként, s csak a fantáziája szabhat határt a lehetséges megoldásoknak. Akkor azonban, ha csak ott akar konkretizálni, ahol ezt az angol fordító is megteszi, sokkal nehezebb megválasztania, hogy mi legyen az az ige, amely a beszélöjelölőben majdnem hatvanszor meg fog ismétlődni a müben. Olyasvalamit kell keresnie, ami az egész müben jól hangzik - ez a feladat sokkal nehezebb.

A Bhagavad-gīta magyar kiadásait megvizsgálva azt látjuk, hogy létezik egy többé-kevésbé egységes hagyomány a beszélőjelölő fordítására. A Kégl Sándor 1910-ben kiadott értekezésében található néhány magyarra fordított versszakban az igy szólt (Kégl 1910: 21), igy szólván és igy szólott (Kégl 1910: 31) alakot találjuk. Valószínüleg a tanulmány elején idézett így szólt, így beszélt és mondotta erre változatokat is mind a beszélöjelölöre utalva használja (Kégl 1910: 5). Gömöryné Maróthy Margit (1924) általában a szól jelen idejü formát részesíti előnyben, az egyetlen kivétel az 1. fejezet 21. versszakában található fordul e szavakkal. A múlt idejü szólt alakot akkor használja, amikor az $u v \bar{a} c a$ nem a beszélöjelölöben, hanem a versszak szövegében jelenik meg, illetve ezek közül az esetek közül egyben (2.1) az ekképpen szólt megoldást választotta. Szabó Lőrinc csak a mü 11. fejezetét fordította le (1958 672-678), s a beszélőjelölőben mindvégig a szólt alakot használja. Noha Baktay Ervin - akinek a kéziratán az 1944-es dátum áll (Baktay 2013: 7) - a beszélőjelölöt ige nélkül fordítja le, a versszakokon belül az így szólt (1.25), így beszélt (2.1) ily szavakkal illeté 
(2.10) és az imígy szólott (3.10) formát választja az uvāca fordítására. Szerdahelyi István Mahábhárata-fordítása mindenütt a szólt formát tartalmazza (Szerdahelyi \& Tóth 1965).

Bhaktivedanta Swami Prabhupāda könyvét Dvārakeśa Dāsa Brahmacārī fordította le magyarra (é. n.). Legtöbbször a szólt alakot választotta, de megtalálhatjuk nála az így szólt, így felelt, folytatta, mondta, kérdezte, válaszolt, igy kérdezett, így válaszolt és a szólott formát is. A könyv későbbi, javított kiadásaiban $(2001,2014)$ az így szólt vált uralkodóvá. A Lakatos István (1987) és Vekeri József (1997) által fordított két Bhagavad-gītā-kiadásban a beszélöjelölő mindenütt az önmagában álló szólt igét tartalmazza. Sebestyén Edit (2000) - ahogyan Dóka Róbert (Śrīdhara 2003) többféle igét is alkalmaz, de mindkettejüknél a szólt a leggyakoribb forma. A Virág László (Abhinavagupta 2012) és a Dienes István (Maharishi 2016) által készített fordításban a beszélöjelölöben kizárólag a szólt alak szerepel, saját verses fordításomban (2016) a hangzó ritmus megtartásának érdekében az ekképp szólt formát alkalmaztam. A Bhagavad-gītā legújabb, Bakos Attila és Judit által készített fordítása szintén sokféle igét használ, ám abban is a szólt fordul elő a leggyakrabban (2017).

A szólt használatának megvan az az előnye, hogy képes érzékeltetni a beszélőjelölő igéje és a Bhaktivedanta Swami Prabhupāda által több helyen is 'szó' (word) jelentéssel fordított, vac gyökből képzett vacas 'beszéd, hang, szó, mondat' (speech, voice, word, sentence) és vacana 'beszéd, mondat, szó, hang, parancs' (speech, sentence, word, sound, voice, order, command) (MonierWilliams 2011) fönevek közötti kapcsolatot. Kérdéses azonban, hogy ez az ige az egyes mondatokban mennyire alkalmas a múlt idejü idéző ige jelentésének visszaadására. Máshogy müködhet, ha a beszélőjelölő egy versszak fordítása elött, egy kétszavas szerkezetben áll (Krș̣na szólt:), és máshogy akkor, ha egy hosszú mondatba ékelődik be (- szólt Arjuna). A fordító elgondolkodhat az igekötős alakok (megszólalt, hozzászólt) használatán, vagy azon, hogy az ige elé helyezett határozószó (igy szólt) mennyire változtatja meg a jelentést, és azon is, hogy nem lenne-e jobb valamilyen más igét (Arjuna beszél:; - mondta Kṛṣna) használni. A mondat elején álló Kṛṣna beszél: forma például jobban kifejezheti a beszélőjelölő semleges regiszterét és jelölői funkcióját, mint a Kṛṣna igy szólt: határozószavas megoldás, ám ha a fordító a jelölöt szeretné beépíteni a versszakok szövegébe, akkor azt ezzel az igével (- beszélt Kṛṣna) aligha tudná megvalósítani.

Az ige konkretizálásának problémája elkerülhető, ha az igét fönév váltja fel:

\section{Sañjaya szavai:}

Mivel a beszélőjelölőnek pusztán narratív funkciója van, az aktivitás érzetét keltő ige használatánál a statikus fönévé talán jobban is illik hozzá, jobban elviseli az ismétlést, és azt is meg lehet vele mutatni, hogy adott esetben az angolban nem a said, hanem az inquired vagy az answered állt:

Arjuna kérdése:

Kṛṣna válasza:

A fentiek fényében a Bhagavad-gìtā As It Is új fordításának elkészítését tervezve a fordítónak a beszélöjelölő magyarra való átültetésekor a következőkre kell figyelnie: el kell döntenie, hogy a szövegbe integrálja vagy elkülöníti a jelölöt, s hogy fog-e benne igét használni. Ha fog, meg kell fontolnia, hogy ragaszkodjon-e a magyar irodalmi fordítási normához, és konkretizálja-e a beszélöjelölő igéjét. Amennyiben a konkretizálást választja, el kell döntenie, hogy fogja-e $\mathrm{s}$ ha fogja, hogyan fogja jelezni, hogy az angol fordító mely versszakok előtt konkretizálta az igét. Ki kell választania egy olyan igét, amelyet azokon a helyeken használ, ahol nem fog konkretizálni, el kell döntenie, hogy ez az általánosan használt szól valamilyen változata lesz, vagy teljesen új utakra lép. 
Bakaja Zoltán: A Bhagavad-gītā As It Is forditásának egyes lexikai problémái

Argumentum 15 (2019), 784-798

Debreceni Egyetemi Kiadó

DOI: 10.34103/ARGUMENTUM/2019/5

\section{A Supreme Personality of Godhead fordítása}

A következő kifejezés szintén kapcsolódik a beszélöjelölőhöz, mert a Bhagavad-gītāban 28-szor fordul elő a jelölő leggyakoribb formája, a śrī-bhagavān uvāca. A formulában szereplő śrī ('szent, nagytiszteletü') szó a megbecsülés kifejezésére szolgál. A szanszkrit bhaga fönév jelentése többek között 'méltóság, fenség, magasztosság', a vat képző pedig 'birtokol vmit, rendelkezik vmivel' értelemben használatos. A fordító a śrī-bhagavān uvāca kifejezést többnyire a the Supreme Personality of Godhead said formulával ülteti át angolra.

Ez a megoldás az 1800-as évek második felére vezethető vissza. Bhaktivinoda Ṭhākura, Bhaktivedanta Swami Prabhupāda gurujának, Bhaktisiddhānta Sarasvatī Gosvāmīnak az édesapja, egy 1871-ben írt esszéjének a The Personality of Godhead címet adta. A bhagavān fordítására megalkotott kifejezést fia is átvette, s ö más formákat is bevezetett, például a the Personality of Transcendental Godhead vagy a the Supreme Personality of Godhead alakot (Sardella 2013: 210). Bhaktivedanta Swami Prabhupāda írásaiban leginkább a the Personality of Godhead és a the Supreme Personality of Godhead fordul elö, de a the Supreme Lord kifejezést is a bhagavān szinonimájaként használja.

Könyvének bevezetésében a következőt írja a bhagavān szó jelentéséről:

Persze a bhagavān szó néha bármely hatalmas emberre vagy félistenre is vonatkozhat, és itt minden bizonnyal azért nevezik így Kṛ̣nát, mert ő egy jelentős személyiség, ugyanakkor tudnunk kell, hogy Kṛ̣na a Supreme Personality of Godhead, ahogyan azt az összes kiváló ācārya (lelki tanítómester), például Śankarācārya, Rāmānujācārya, Madhvācārya, Nimbārka Svāmī, Śrī Caitanya Mahāprabhu és India védikus tudományának más szaktekintélyei is megerösítik (Bhaktivedanta 2015: 2-3). ${ }^{6}$

A 10. fejezet 1. versszakának magyarázatában egy másik definíciót is találunk:

Parāśara Muni így magyarázza el a bhagavān szó jelentését: az Bhagavān, a Supreme Personality of Godhead, aki teljes mértékben rendelkezik a hatféle gazdagsággal, azaz ő a legerősebb, leghíresebb, leggazdagabb, legszebb, mindent ismer és mindenről lemond. ${ }^{7}$

Sok nemzet fordítója számára jelent problémát a the Supreme Personality of Godhead-nek a saját nyelvére való átültetése. A Bhaktivedanta Book Trust weboldaláról letölthető fordítói kézikönyvben találhatunk egy levelezést (7. URL: 53-54), amelyben többen is leírják, hogy nyelvükön a grammatikai nem egyeztetésének kényszere miatt a Kṛṣnára, az őseredeti férfire vonatkozó kifejezés nőnemüvé válik.

A hozzászólásokból az is kiderül, hogy a résztvevők némelyike magát a kifejezést sem értette:

Śrīla Prabhupāda Balarāma, Nṛsimhhadeva, Nārāyaṇa, a Feletteslélek stb. esetében is használja ezt a kifejezést, amely úgy tünik, hogy nem mindig Śrī Kṛṣnára, az Istenség azon személyiségére utal, aki az összes többi felett áll. ${ }^{8}$

Ennek a félreértésnek az az oka, hogy a personality ('személyiség') a magyarhoz hasonlóan egyaránt vonatkozhat egy ember híres, kiváló voltának és az egyéni vonásainak a megjelölésére is ( 8 .

6 Of course the word bhagavān sometimes refers to any powerful person or any powerful demigod, and certainly here bhagavān designates Lord Śrī Krș̣na as a great personality, but at the same time we should know that Lord Śrī Kṛ̦ṇa is the Supreme Personality of Godhead, as is confirmed by all great ācāryas (spiritual masters) like Śankarācārya, Rāmānujācārya, Madhvācārya, Nimbārka Svāmī, Śrī Caitanya Mahāprabhu and many other authorities of Vedic knowledge in India.

7 The word bhagavān is explained thus by Parāsara Muni: one who is full in six opulences, who has full strength, full fame, wealth, knowledge, beauty and renunciation, is Bhagavān, or the Supreme Personality of Godhead.

8 „Śrīla Prabhupāda uses this expression also for Balarāma, Nṛsimhadeva, Nārāyaṇa, the Supersoul, etc. So it seems to not always refer to the supreme amongst all personalities of Godhead, Śrī Kṛ̣ṇa.” 
Bakaja Zoltán: A Bhagavad-gītā As It Is forditásának egyes lexikai problémái

Argumentum 15 (2019), 784-798

Debreceni Egyetemi Kiadó

DOI: $10.34103 / A R G U M E N T U M / 2019 / 5$

URL). ${ }^{9}$ A bengáli-vaiṣnava teológia szerint a fentebb található nevek - Balarāma, Nṛsimhadeva, Nārāyaṇa stb. - Isten olyan alakjait jelölik, amelyeket ha felölt, más isteni tulajdonságai kerülnek előtérbe, mint az eredeti, Kṛṣnának nevezett formájában. Habár e formák nem különböznek egymástól, ahogyan a színész is önmaga marad szerepei eljátszása közben, az Úr Kṛ̣nạának nevezett alakja fölötte áll az összes többinek, mert ebben mutat meg magából a legtöbbet, s a szeretet legnagyobb mélységei is csak az előtt tárulnak fel, aki Kṛ̣naként imádja öt.

A the Personality of Godhead vagy a the Supreme Personality of Godhead helyes leforditásához fontos tudnunk, hogy ezek a kifejezések nem birtokviszonyt jelölnek, használatukkal nem Isten személyiségéről, hanem magáról Istenről, a jeles személyiségről beszélünk. Úgy kell értelmeznünk öket, mintha a Budapest városa vagy a Budapest gyönyörü városa formákat használnánk, amelyekben a város nem Budapest birtoka, hanem maga Budapest. A Personality tehát nem a birtoka a Godhead-nek, hanem az értelmező jelzője. Mindezt a kézikönyv 53. oldalának alján található levélrészlet is alátámasztja:

„»Ami kérdésedet illeti, két lehetőséged van. Mondhatod azt, hogy Krishna Isten, a Legfőbb Személyiség és azt, hogy Isten, a Legfőbb Személy« (Levél Jyotirmayinak 72-05-28)."10

A kézikönyv 53. oldalán idézett beszélgetésből megtudhatjuk, hogy Bhaktivedanta Swami Prabhupāda azért tartotta jobbnak a God-nál a Godhead kifejezést, mert bizonyos hindu irányzatok filozófiája szerint a megvilágosodás állapotában a lélek úgy egyesül Istennel, hogy azonossá válik vele. Az ő értelmezésében a Godhead szó a benne lévő head-del ('fej') megmutatja, hogy Kṛ̣ṇa fölötte áll mindenkinek, senki sem válhat Kṛ̣nạáá.

A szótárban a három szónak a következő jelentéseit találjuk meg:

\begin{abstract}
supreme mn 1. legfelső(bb), legföbb, legfontosabb; the Supreme Being Isten, a legföbb lény; supreme commander fövezér; jog supreme court (of judicature) legfelsőbb bíróság/törvényszék; kúria; US Supreme Court of the U. S. az Egyesült Államok legfelsőbb bírósága; tört Supreme Soviet Legfelsőbb Tanács [volt SZUban] 2. páratlan, végső, döntő; supreme sacrifice az élet feláldozása; ir the supreme hour az utolsó óra, a halál órája; biz hold sy in supreme contempt nagyon/mélységesen megvet vkt, le se köp vkt 3. mindenek fölött való, átv legmagasabb; supreme folly a lehető legnagyobb bolondság; supreme among poets a legkiválóbb költő.
\end{abstract}

personality $f n$ 1. a) személy(iség); jog legal personality jogi személy b) kiváló/kimagasló személyiség, kiválóság; personality cult személyi kultusz 2. a) egyéniség; split personality lelki hasadás, tudathasadás, s(z)kizofrénia; thinking personality észember; be lacking in personality nincs egyénisége b) egyéni jelleg 3. személyes/személyi/egyéni/magánjellegü volta (vmnek) 4. a) személyeskedő éle/volta [megjegyzésnek] b) personalities $t s z$ személyeskedés; indulge in personalities személyeskedik 5 . ritk $\rightarrow$ personalty.

$\operatorname{godhead} f n$ istenség; the Godhead az Isten.

A supreme szótári jelentései közül a 'legfelső, legfelsőbb, legfőbb, legfontosabb, páratlan, mindenek fölött való' az, amit használhatunk. A personality fordítására a 'személy, személyiség, kiváló/kimagasló személyiség, kiválóság' a godhead esetében pedig az 'istenség, Isten' jelentéseket találjuk. A jelentések közül válogatva meg kell vizsgálnunk, hogy melyek egyeznek meg a lefordítani kívánt kifejezésben aktuálisan megvalósuló jelentéssel, azaz a forrásnyelvi megfelelő értelmével, és mely kombinációjuk képes többféle szövegkörnyezetben vagy akár címként is jól funkcionálni. A kifejezésnek könnyen érthetőnek kell lennie, valamint meg kell felelnie az irodalmi normának. Megvizsgálhatjuk, hogy lehetséges vagy szükséges-e egy formálisan is ekvivalens párt találnunk, és mindent meg kell tennünk annak érdekében, hogy a kapott alak ne legyen félreérthetö.

9 The type of person you are, shown by the way you behave, feel, and think: She has a very warm personality. A famous person: The show is hosted by a popular TV personality.

10 „So far your question is concerned there are two possibilities. You may say that Krishna is God the Supreme Personality and God the Supreme Person..." 
Bakaja Zoltán: A Bhagavad-gītā As It Is forditásának egyes lexikai problémái

Argumentum 15 (2019), 784-798

Debreceni Egyetemi Kiadó

DOI: 10.34103/ARGUMENTUM/2019/5

Mivel a supreme a már korábban megalkotott Personality of Godhead-hez kapcsolódik, először ez utóbbi kifejezés fordításának a mikéntjéről kell dönteni.

A fenti szempontokat figyelembe véve az Istenség Személyisége tükörfordítást rögtön el is vethetjük. A fordítástudományban vagy a fordítás gyakorlatában járatos emberek számára nem újdonság, hogy a tükörfordítás rossz minőségű szöveget eredményezhet, ebben az esetben azonban fontolóra kell vennünk, hogy filozófiai szövegek esetén fontos lehet a formális megfelelés (lásd Nida 1964: 165, Albert 2011: 199-224). Itt két dologra kell emlékeznünk:

1) A śrī-bhagavān uvāca fordításakor Bhaktivedanta Swami Prabhupāda maga sem él a formális megfeleltetés lehetőségével. A śrī általában teljesen kimarad a fordításából (kihagyás), a bhagavān-t pedig három olyan szóval ülteti át angolra, amelyek egyike sem szerepel a bhaga fónév és a vat képző szó szerinti jelentései között. Amikor a 'fenséges'-t, 'magasztos'-t jelentő bhagavat-ot a Supreme Personality of Godhead kifejezéssel adja vissza, akkor konkretizál, világosan kifejti, hogy a magasztos szó alatt Istent, azt a lényt érti, aki mindenkinél kiválóbb, s aki mindenek felett áll. Számára a bhagavān szó nem holmi homályos tartalmú magasztosságra utal, hanem Isten három aspektusa, a Brahman, a Paramātmā és a Bhagavān közül a harmadikra. Nem a mindent átható személytelen Lélek, nem a szívben élő, felülvigyázó és irányító Feletteslélek, hanem az a mindezek és mindenek felett álló személy, aki a csatában Arjuna iránti szeretetéből fakadóan híve kocsihajtója lesz, tanítja öt és védelmezi.

2) A birtokos szerkezettel egybekötött, több jelentésü personality használata miatt a forrásnyelvi szöveg önmaga is kétértelmü, és a téves értelmezése pont egy filozófiai jellegü félreértésre ad okot, így a forrásnyelvi szövegnek való formális megfeleltetés nem segíteni, inkább veszélyeztetni fogja a filozófiai tartalom megértését. Ezt a gyakorlatban is tapasztaltam, amikor a jelenlegi formahü magyar fordítást olvasva én magam is feltettem és másoktól is többször hallottam a fentebb idézett kijelentésre hasonlító kérdést: „Miért nevezi a szerző Viṣnut is az Istenség Legfelsőbb Személyiségének?"

Az Istenség Személyisége alak kétértelmüségében nemcsak a birtokos szerkezetnek az egyébként is a kétértelmüséget segítő hatása érvényesül, magának a személyiség szónak a kettős értelme is azt erősíti (Kiss 2007):

1. Jelentős személy. A kiállítás megnyitásán több magas állású közéleti személyiség is megjelent.

2. Az ember mint egyéni tulajdonságokkal rendelkező személy. Pszichológusként az emberi személyiség sajátosságai foglalkoztatják.

A köznyelvben a személyiség gyakrabban utal a karakterre, mint valakinek a prominens voltára, így ha azt mondom, hogy ,a rend fenntartására a rendőrfőnök személyisége volt a garancia”, akkor a személyiség szóról a legtöbb hallgatónak a rendteremtéshez ideális habitus fog eszébe jutni, nem pedig a rendörfönök hivatali minősége. Ha ez utóbbira akarok utalni, akkor azt mondom, hogy ,a rend fenntartására a rendörfőnök személye volt a garancia".

A personality jelentéseinek fentebb felsorolt alkalmazási lehetőségeit figyelembe véve, maradt az Isten/Istenség személye és a kiváló Isten/Istenség változat, vagy ha egy kicsit elrugaszkodunk a szótárban található szavaktól, a hatalmas Isten/Istenség, és a magasságos Isten. Azt megfontolva, hogy a supreme lefordításával még egy jelzőt bele kell szerkesztenünk a formulába, arra jutunk, hogy az Isten/Istenség személye az, amely formailag is a legközelebb áll az eredetihez, ugyanazt az értelmet hordozza, és nem is olyan nehézkes, mint a jelzőhalmozással fenyegető változatok.

Ha az isten és az istenség között akarunk dönteni, akkor célszerü elvégezni egy Google-keresést és máris láthatjuk, hogy a kettő közül az első kap jóval több találatot $(\sim 11900 \quad 000 / \sim 158 \quad 000$ elvégezve: 2019.09.04.), sokkal gyakrabban használatos, mint a második. A Bhagavad-gìtā és a Bhagavad-gītā As It Is széles célközönséghez szól - ahogy a szerző mondja: baráthoz és ellen- 
séghez egyaránt (1.10) -, ezért célszerü olyan nyelven fogalmaznunk, hogy a lehető legkönnyebben megértse mindenki. Mivel az istenség formát viszonylag szük körben használják (és néha a többistenhitre utal), véleményem szerint jobb az isten alakot választani. Emlékeznünk kell arra, hogy a könyv nem tudósoknak szánt filológiai munka, hanem felhívásközpontú alkotás (lásd Reiss 1985: 267-269), amelynek az a célja, hogy a befogadó helyesen, s minél könnyebben értse meg, sajátítsa el és gyakorolja az olvasottakat. Ráadásul a szótárban a the Godhead fordítása: 'az Isten'. Magyar nyelvterületen nem kell tartani attól, ami miatt az angol fordítás készítője a God helyett a Godhead formát választotta. Az Isten szó az emberek többsége számára nem olyasvalakit jelent, akivel eggyé, azonossá válhatna. Ennek fényében a Personality of Godhead fordításául az Isten személye vagy az Isten formát javaslom.

A supreme jelentésének bemutatásánál a szótár a 'legföbb'-et eleve vallásos kontextusba helyezi, de jól használható a 'mindenek felett való' és a 'páratlan' is, így hat kifejezésünk lesz:

(1) Isten legföbb személye,(2) a legföbb Isten, (3) Isten mindenek felett való személye (4) a mindenek felett való Isten (5) Isten páratlan személye. (6) a páratlan Isten.

Egy indiai vallási irányzattal kapcsolatban elkerülhetetlenül felmerül a politeizmus gondolata. Ha a fentebb felsorolt kifejezések elé helyezzük a Kṛ̦̣̣a szót, ahogy az gyakorta szerepel az angolban (Kṛșna is the Supreme Personality of Godhead), nem szabad, hogy az olvasó azt gondolja, Kṛ̣na pusztán egy sok istenböl álló panteon vezető istensége. Ez néhány esetben, például a Kṛ̣nạa a legföbb Isten használatával valós veszély lehet.

Egy az ELTE BTK Müfordító Mühelyének kiadásában megjelent fordításomban (2017: 136141) a harmadik megoldást választottam, és Hetényi Zsuzsa professzor asszony tanácsára a végső változat az Isten mindenek fölött álló személye lett. A fölött használatával elkerülhetjük, hogy a felett-ben lévő túl sok $e$ miatt a kifejezés mekegőssé váljon, a való-t pedig ritkának minősíti a Magyar értelmezö kéziszótár (Pusztai 2011), s az álló használata választékosabb és természetesebbnek is hat. A felsorolt variációk a lehető leghübben követik az angol kifejezés formáját. Ezek mellett ott vannak a formálisan nem ekvivalens, de a szerző által javasolt megoldások, amelyeket fentebb már idéztem: Isten, a Legföbb Személyiség, illetve Isten, a Legföbb Személy. Utóbbiak esetében azt kell figyelembe venni, hogy a vesszők használatának szükségessége nehézkesebbé teszi a szöveget. A kézikönyv 54. oldalán egy másik idézetet is találunk: „Ami a kérdésedet illeti, mindig helyettesítheted [a kiemelés tőlem] a 'Supreme Personality of Godhead' szavakat valamilyen ekvivalensükkel" Il Ilyen lehet a szerző által használt Supreme Lord magyar fordítása: legföbb/ páratlan/mindenek fölött álló Úr, vagy bármely más azonos értelmet hordozó kifejezés. Mivel a szerző a Supreme Lord, Supreme Personality of Godhead és Personality of Godhead formulákat szinonimákként használja könyveiben, ha valamelyikükre találunk egy olyan kifejezést, amely sokkal jobb a másik kettő fordításánál, akár mindhárom esetben alkalmazhatjuk.

\section{A living entity fordítása}

Az Angol-magyar nagyszótár szerint az entity jelentése: „1. fil entitás, a létező tulajdonságainak összessége 2. infor entitás, valós elem 3. legal entity jogi személy.” Az Idegenszó-tár (Tótfalusi 2008) szerint az entitás jelentése 'valamely lénynek, létező dolognak konkrét mibenléte, tulajdonságainak összessége'. A Cambridge Dictionary viszont egészen másféle értelmezést ad az entity szónak: 'olyan dolog, amely mivel önállóan létezik, különbözik másoktól' (9. URL). ${ }^{12}$

Ahogyan azt látni fogjuk, Bhaktivedanta Swami Prabhupāda is az utóbbi értelemben használja a szót, amelyet a Bhagavad-gītā As It Is-ben a következö szanszkrit szavak fordítására használ: ātman

11 „Regarding your question, you can always use some equivalent to the words 'Supreme Personality of Godhead."”

12 Something that exists apart from other things, having its own independent existence. 
(5.16, 6.6, 6.8), puruṣa (13.22), bhūta (13.35), dehina (14.5). Monier-Wiliams szótára szerint ezek mindegyike rendelkezik a 'lélek' (soul) jelentéssel; az utolsó kettőt akkor használhatjuk a lélekkel kapcsolatban, amikor az anyagi testet öltött.

A magyarázatokból azt tudhatjuk meg a living entity-ről, hogy sok minden megtévesztheti; nem szabad azt hinni, hogy ő Isten (5.16); alkata szerint szolga (6.6); a természet erőinek a játékszere; egy bizonyos idő elteltével egy másik testbe kell költöznie; azt gondolja, hogy a kedve szerint alakíthatja a körülményeit; $\mathrm{s}$ ahogy fokozatosan megválik a természet uralására irányuló vágyától, lelki boldogságot nyerhet (13.22). Az anyagi természettel való kapcsolata megköti, s noha nincs köze az anyagi természethez, megkötött állapotában a természet adta testeknek megfelelöen cselekszik (14.5).

A fordítási probléma abból fakad, hogy a szótárak tanúsága szerint a magyar entitás nem ugyanazt jelenti, mint ez esetben az angol entity. Az élö entitás egyébként is nagyon idegenül hangzana és az olvasó nem értené meg belőle, hogy itt a lélekről beszélünk. Az egység szó talán visszaadhatná a 'más dolgoktól különbözö' jelentést, de az olvasó az élö egység-et sem fejtené meg sokkal könnyebben, mint az élö entitás-t. A jelenlegi magyar kiadásban (Bhaktivedanta 2014) az élölény szerepel a kifejezés fordításaként. Ez a szó a Magyar értelmező kéziszótár szerint 'anyagcserét folytató, szaporodó élő szervezet'-et jelent, az Értelmező szótár + szerint pedig 'élő személy, állat vagy növény' jelentéssel rendelkezik, azaz nem az anyag fölött álló lélekre, hanem a biológiai lényekre utal.

A living entity fordítására a legjobb megoldás talán a lélek szó használata lenne, s ebben az esetben az élö feleslegessé válna, hiszen a Bhagavad-gītā tanítása szerint a lélek csakis élö lehet. A lélek azonban önmagában nem elég, a szerző az entity-vel azt akarta hangsúlyozni, hogy ez a lélek nem azonos sem Istennel, sem azokkal a lényekkel, akik épp más testben élnek. A szó elé mindenképpen szükséges valamilyen jelző. Bhaktivedanta Swami Prabhupāda a lélek egyéni voltának a kifejezésére az individual soul-t is használja (2.24) ezért talán ennek a magyar megfelelöje a living entity jelentésének a visszaadására is alkalmas. A fordító tehát az egyéni vagy egyedi lélek kifejezést használhatná mind az individual soul, mind pedig a living entity fordítására is. Ezzel a szöveg talán veszítene a változatosságából (a tanulmány tárgyául választott müben van olyan magyarázat, amelyben mindkét angol kifejezés szerepel, ezért zavaró mennyiségű szóismétlést okozna, pl.: 2.23), viszont pontosabban, kevésbé félreérthetően tükrözné vissza a living entity jelentését.

\section{$5 \quad$ A self-realization fordítása}

Az Angol-magyar nagyszótár a self-realization megfelelöjeként a 'önmegvalósítás, önmaga kiteljesítése' jelentéseket adja meg. A Magyar értelmezö kéziszótár szerint az önmegvalósitás jelentése: „Vki képességeinek, hajlamainak kibontakoztatása, vágyainak kiélése”. A Bhagavad-gītā As It Is-ben azonban a szó más értelemben való használatával találkozunk.

A 2. fejezet 53. versszakában a kifejezés a yoga fordításaként található meg, s a magyarázatban a szerző arról ír, hogy a self-realization legtökéletesebb formája Isten három aspektusának, a Brahman-nak, a Paramātmā-nak és a Bhagavān-nak a megismerése. A szerző a 3. fejezet 17. versszakában a self-illumination ('a saját kilétünket felfedő megvilágosodás') szinonimájaként használja, s a fejezet 34. versszakának a fordítása szerint az érzéki vágyak kielégítése akadályokat képez a self-realization útján. Később, a 41. versszak szószedetében egy definícióját is megtaláljuk: 'a tiszta lélek tudományos ismerete'. ${ }^{13}$ A 12 . fejezet 20. versszakának magyarázatában az áll, hogy a self-realization önmagunk Istennek való átengedése által érhető el. ${ }^{14}$

13 Scientific knowledge of the pure soul. 
A probléma a realization fordításából fakad. Ennek az egyik jelentése 'teljes mértékben tudatára ébredni valaminek' (megrémít az, hogy ráébredtem milyen sokban különbözünk), ${ }^{15}$ illetve 'valaminek a beteljesítése, valóra váltása' (nem érte meg, hogy megláthassa, amint az álma valóra válik) ${ }^{16}(10$. URL).

A Bhagavad-gītā As It Is-ben található self-realization kifejezés esetében az előbbi jelentés valósul meg, így annak értelme nem az önmegvalósitás, hanem az önmegismerés. Azt, hogy a szövegben alkalmazott végső forma önmegismerés, önmagunk meg-, illetve felismerése, a lélek megismerése, vagy valami más lesz, a szövegkörnyezet fényében érdemes eldönteni.

\section{6 Összefoglalás}

Tanulmányomban az A. C. Bhaktivedanta Swami Prabhupāda könyvében, a Bhagavad-gìtā As It Isben található öt szó, illetve kifejezés: a beszélöjelölö igéje, a Personality of Godhead, a Supreme Personality of Godhead, a living entity és a self-realization magyar fordítása során felmerülö lexikai fordítási problémákat vizsgáltam meg. Számba vettem néhány megoldási lehetőséget, de ez koránt sem jelenti azt, hogy teljes mértékben kimerítettem volna a nyelvünkben rejlő alternatívákat. Terjedelmi okok miatt nem térképeztem fel a tárgyalt kifejezések összes megjelenési helyét, nem vizsgáltam meg minden részletre kiterjedően a szövegkörnyezetüket, noha az nagyban befolyásolhatja, hogy a fordító végül melyik változat mellett dönt. A Bhagavad-gìtā As It Is jóval több nehezen fordítható kifejezést tartalmaz, ezekről szintén terjedelmi okok miatt nem szóltam. Közhely, hogy a jó fordító, mielőtt munkához kezd, elolvassa a lefordítandó müvet. Ennél azonban tovább is mehet, áttanulmányozhatja a szerző által hátrahagyott teljes korpuszt, és amennyiben elérhetőek, megvizsgálhatja a lektorálás előtti szövegeket is, amelyek még árnyaltabban megmutathatják, milyen értelmet szánt a szerző az egyes kifejezéseknek. Ha a kutató ezeket ilyen alapos vizsgálatnak veti alá, akkor már a Bhaktivedanta-korpuszban található egyetlen kifejezéssel kapcsolatos adatmennyiség feldolgozása is kimerítheti, de könnyen meg is haladhatja egy cikk vagy tanulmány tartalmi kereteit.

\section{Források}

Abhinavagupta (2012): Gītārthasamigraha. Ford. Virág, L. Budapest: Perisca Kiadó.

Bakaja, Z. (ford.) (2016): Bhagavad-gítá: részlet. In: 5pofon. Budapest: ELTE BTK Müfordító Mühely.

Bakos, A. \& Bakos J. E. (2017): Bhagavad gìtā. Budapest: Dhanvantara Kiadó.

Baktay, E. (2013): A Magasztos Szózata. Budapest: Filosz Kiadó.

Bhaktivedanta Swami, A. C. (1968): The Bhagavad Gita As It Is. London: Collier - Macmillan Ltd.

Bhaktivedanta Swami Prabhupāda, A. C. (1972): Bhagavad-gītā As It Is. New York: Collier Books, London: Collier Macmillan Publishers.

Bhaktivedanta Swami Prabhupāda, A. C. (2015): Bhagavad-gītā As It Is. [h. n.]: The Bhaktivedanta Book Trust.

Bhaktivedanta Swami Prabhupāda, A. C. (é. n.): Az eredeti Bhagavad-gītā. Ford. Dvārakeśa. Vaduz: The Bhaktivedanta Book Trust.

Bhaktivedanta Swami Prabhupāda, A. C. (2001): A Bhagavad-gītā úgy, ahogy van. Ford. Dvārakeśa és mások. [h. n.]: The Bhaktivedanta Book Trust.

15 In fact, the realization that so many differences exist between us is beginning to be daunting.

16 He did not live to see the realization of his dream. 
Bakaja Zoltán: A Bhagavad-gìtā As It Is forditásának egyes lexikai problémái

Argumentum 15 (2019), 784-798

Debreceni Egyetemi Kiadó

DOI: $10.34103 / A R G U M E N T U M / 2019 / 5$

Bhaktivedanta Swami Prabhupāda, A. C. (2014): A Bhagavad-gītā úgy, ahogy van. Ford. Dvārakeśa és mások. [h. n.]: The Bhaktivedanta Book Trust.

Christie, A. (1968): Tíz kicsi néger. Ford. Szíjgyártó, L. Budapest: Európa Kiadó.

Gömöryné Maróthy, M. (ford.) (1924): Bhagavad-Gitá az isteni ének. Budapest: Légrády Nyomda és Könyvkiadó.

Kégl, S. (1910): Bhagavadgîtâ. Budapest: Magyar Tudományos Akadémia.

Kiss, G. (szerk.) (2007): Értelmezö szótár. Budapest: TINTA Könyvkiadó.

Lakatos, I. \& Vekerdi, J. (ford.) (1987): A magasztos szózata Bhagavad-gítá. Budapest: Európa Kiadó.

Maharishi, M. (2016): A Bhagavad-gitá: Új formátumban és új magyarázattal. Ford. Dienes, I. [h. n.]: Vaszistha Kft.

Monier-Williams, M. (2011): A Sanskrit-English Dictionary. Delhi: Motilal Banarsidass Publishers.

Newmark, P. (1988): A textbook of Translation. New York: Prentice Hall International.

Országh, L.\& Magay, T. (2009): Angol-magyar nagyszótár. Budapest: Akadémiai Kiadó.

Pusztai, F. (föszerk.) (2011): Magyar értelmezö Kéziszótár. Budapest: Akadémiai Könyvkiadó.

Sebestyén, E. (ford.) (2000): Bhagavad Gita. Budapest: Sri Sathya Sai Baba Szervezet Magyarországi Központja.

Śrīdhara Deva Gosvāmī, B. R. (2003): Bhagavad-Gìtā: Az Édes Abszolút rejtett kincse. Ford. Dóka, R. [h. n.]: Harmónia Alapítvány.

Szabó, L. (1958): A mindenség látomása: A Bhagavadgita XI. éneke. In: Örök barátaink I. 672678. Budapest: Szépirodalmi könyvkiadó.

Szerdahelyi, I. \& Tóth, E. (ford.) (1965): Mahábhárata. Budapest: Európa Könyvkiadó.

Tótfalusi, I. (2008): Idegenszó-tár. Budapest: Tinta Könyvkiadó.

\section{Online források}

1. URL:

Bhaktivedanta Swami Prabhupāda, A. C. (1968): The Bhagavad Gita As It Is. London: Collier Macmillan Ltd. http://vanisource.org/wiki/Bhagavad_Gita_As_It_Is_(1968)_CollierMacmillan_Abridged_Edition (Az oldal utolsó megtekintésének időpontja 2018.12.31.)

2. URL:

Bhaktivedanta Swami Prabhupāda, A. C. (1972): Bhagavad-gītā As It Is. New York: Collier Books, London: Collier Macmillan Publishers. http://vanimedia.org/w/images/7/7a/197273_Bhagavad_gita-As_It_Is.pdf(Az oldal utolsó megtekintésének időpontja 2018.12.31.).

3. URL:

Bhaktivedanta Swami Prabhupāda, A. C. (1983): Bhagavad-gītā As It Is. [h. n.]: The Bhaktivedanta Book Trust. https://www.vedabase.com/en/bg (Az oldal utolsó megtekintésének időpontja 2018.12.31.).

6. URL:

https://www.vedabase.com/en/synonyms-

index?original_op $=$ contains\&original $=\mathrm{uv} \% \mathrm{C} 4 \% 81 \mathrm{ca} \&$ translation_op $=$ contains\&translation $(\mathrm{Az}$ oldal utolsó megtekintésének időpontja 2018.12.31.).

8. URL:

http://dictionary.cambridge.org/dictionary/english/personality?a=british (Az oldal utolsó megtekintésének időpontja 2018.12.31.). 
9. URL:

http://dictionary.cambridge.org/dictionary/english/entity (Az oldal utolsó megtekintésének időpontja 2018.12.31.).

10. URL:

https://en.oxforddictionaries.com/definition/us/realization (Az oldal utolsó megtekintésének időpontja 2018.12.31.).

\section{Irodalom}

Albert, S. (2011): „A fövenyre épitett ház”: A forditáselméletek tudomány és nyelvfilozófiai alapjai. Budapest: Áron Kiadó.

Bhaktivedanta Swami Prabhupāda, A. C. (2017): A Bhágavata fénye (részlet) In: 6Pofon: müforditás-antológia. Budapest: ELTE BTK MüMü.

Klaudy, K. (1999): Bevezetés a forditás gyakorlatába. Budapest: Scholastica.

Klaudy, K. \& Simigné Fenyő S. (2000): Angol-magyar fordítástechnika. Budapest: Nemzeti Tankönyvkiadó.

Körtvélyesi, T. (2006): Szanszkrit nyelvtan. Budapest: A Tan Kapuja Buddhista Főiskola.

Mujzer-Varga, K. (2007): A reáliafogalom változásai és változatai. Forditástudomány 19/2, 55-84.

Nida, E. A. (1964): Toward a Science of Translating. Leiden: E. J. Brill.

Sardella, F. (2013): Modern Hindu Personalism. New York: Oxford University Press. https://doi.org/10.1093/acprof:oso/9780199865918.001.0001.

Reiss, K. (1985): Szövegtipológia és fordítás. In: Bart I. \& Klaudy K. (szerk.): A forditás tudománya. Budapest: tankönyvkiadó. 253-271.

\section{Online irodalom}

4. URL:

The Bhaktivedanta Book Trust (BBT). http://bbt.org (Az oldal utolsó megtekintésének időpontja 2018.12.31.).

5. URL:

The official website of the International Society for Krishna Consciousness (ISKCON). http://www.iskcon.org/ (Az oldal utolsó megtekintésének időpontja 2018.12.31.).

7. URL:

Gaura Vigraha-devī dāsī The BBT Manual for Translators, Editors and Proofreaders www.bbt.se/Manuals/BBT_manual.pdf (Az oldal utolsó megtekintésének időpontja 2018.12.31.).

Bakaja Zoltán

ELTE BTK Irodalomtudományi Doktori Iskola

1088 Budapest

Múzeum krt. 4/A, 3. em., 319.

zoltan@bakaja.hu 